\title{
THE ROLE OF BIOENERGY IN TRANSITION TO A SUSTAINABLE BIOECONOMY - STUDY ON EU GOUNTRIES
}

\author{
Ştefan Dragoş Cîrstea ${ }^{1 *}$, Andreea Cîrstea ${ }^{2}$, Irimie Emil Popa ${ }^{3}$ \\ and Gabriel Radu ${ }^{4}$ \\ ${ }^{1)}$ Technical University, Cluj-Napoca, Romania. \\ ${ }^{23)}$ Babeş-Bolyai University, Cluj-Napoca, Romania \\ 4) The University of Economic Studies, Bucharest, Romania
}

Please cite this article as:

Cîrstea, Ș.D., Cîrstea, A., Popa, I.E. and Radu, G., 2019. The Role of Bioenergy in Transition to a Sustainable Bioeconomy - Study on EU Countries. Amfiteatru Economic, 21(50), pp. 75-89

\section{Article History}

Received: 29 September 2018

Revised: 18 November 2018

Accepted: 15 December 2018

DOI: $10.24818 / \mathrm{EA} / 2019 / 50 / 75$

\begin{abstract}
Starting with the significant differences between the European Union member states regarding the implementation of the sustainable development goals stipulated by the United Nations and the transition from the fossil fuel economy to the one based on the principles of bio-economics, the article aims highlighting the correlation between the bioenergy production and a range of economic, environmental or innovation indicators for each Member State.

The designed model uses data for 25 EU Member States collected for the period 2007-2013. The novelty of this study derives from the use of linear regression to estimate the impact of bioenergy evolution on the country's energy dependence and Panel Least Squares to identify the correlations between bioenergy and fossil fuel production, PIB per unit of energy use, the degree of innovation in the field and renewable energy generation.

The obtained results show that the bioenergy-renewable-energy-dependency relationship is not significantly influenced by the economic crisis, even if the proposed model is weaker. At the same time, bioenergy positively correlates with the degree of innovation in the field or with the energy from natural gas and negatively with the economic efficiency of a state. The article presents the gap between countries regarding bioenergy, as well as their evolution during the analyzed period. All these values support the positive effects that bioenergy will have on the sustainable development of the bioeconomy. Bioenergy production can make a significant contribution to mitigating climate change while ensuring the diversification of energy resources in the long run.
\end{abstract}

Keywords: bioenergy, bioeconomy, innovation, GDP per energy use, energy dependence, European Union

JEL classification: Q56, Q40, Q29, O10, C23

* Corresponding author, Ştefan Dragoș Cîrstea - stefan.cirstea@enm.utcluj.ro 


\section{Introduction}

Implementing a biodiversity-based economy faces several challenges related to the sustainability of natural resource management, food security, mitigation and adaptation to climate change and maintaining competitiveness (Scarlat et al., 2015). At the same time, contemporary society is concerned about complex sustainable development both from a energy perspective and from a much broader view, such as responsible consumption (Do Paco et al., 2013; Dabija et al., 2018), ecological products (Kirmani et al., 2016), sustainable marketing (Dabija and Pop, 2013) or sustainable academic development (Fonseca et al., 2011). Major greenhouse gas mitigation scenarios show that a $25 \%$ bioenergy contribution is possible in primary energy consumption (GEA, 2011, IEA, 2011, OECD / IEA, 2011, IPCC, 2014).

Bioeconomy can be defined as an economy where primary resources for materials, chemicals or energy come from renewable biological resources (McCormick and Willquist 2015). Within the broader concept of the green economy, the bioeconomic vision focuses on the use of renewable raw materials and the application of industrial biotechnology research, development, and innovation in sectors such as food, food, paper, and cellulose or energy (Scarlat et al., 2015). Current economic growth depends on the production and consumption of energy (Ozturk et al., 2010; Wang et al., 2016). The transition from the traditional economy to the bioeconomy requires the adaptation of the way energy is generated. Even if constant research in this field can be identified, bioenergy is continuously subject to technical, economic, environmental, legislative or innovative regulation. In the context of the current 4.0 Industrial Revolution, a new concept has emerged that will soon become a quite studied and publicized, Globalization 4.0 (WEF, 2018). It can be said that bioeconomy can become the basis of this new concept, and bioenergy can represent the driving force necessary for its development. Also, energy security or the reduction of a state's energy dependency is and will be a subject that requires constant attention. Therefore, the lack of studies showing the contribution of bioenergy to reducing a country's energy dependence can be highlighted. At the same time, the need to identify the existing correlations between bioenergy production and economic, environmental or innovation indicators is a segment that needs to be given greater attention.

Based on the motivation mentioned above, the main objective of this study is to investigate the economic, innovative and environmental role that bioenergy has in the transition to a sustainable bioeconomy, highlighting the primary determinants that have a positive or negative impact on this area. The investigation is based on representative indicators for each dimension, such as bioenergy production, energy dependency, GDP per unit of energy use or the number of new patents in the field. From an empirical point of view, the paper combines quantitative analysis tools with qualitative analysis ones, the result is the testing of a proposed model by means of a regression equation that emphasizes the determination and implications of specific independent variables on the dependent variable, bioenergy production, and scaling multidimensional gap between the European Union (EU) countries in the field of renewable energy and bioenergy.

The article contains five parts, the first being dedicated to the argumentation of the chosen topic, and the second highlights the significant researches and their results in the sphere of bioenergy. The third section presents the research methodology, while the fourth highlights the results obtained, along with a series of discussions on their impact. At the end of the article, conclusions, study boundaries, and future research directions are synthesized. 


\section{Literature review}

\subsection{Current implications of bioenergy in bioeconomy}

The concept of a bio-based economy, the so-called "bioeconomy" is guiding to the search for new alternatives to replace the fossil fuel-based economy. Bioeconomy mainly includes: (a) sustainable production of renewable bioresources to minimize both anthropogenic impacts on the climate and dependence on fossil products; and (b) increasing the added value of biomass materials with low resource consumption (Sillanpää and Ncibi, 2017). Thus, an important direction for creating a sustainable bioeconomy is: (a) assessing the potential of bioresources, (b) transforming bioresources into more products, (c) nutrient recycling or interrelationships between adaptation strategies to climate change (Silveira et al., 2017). The Bioeconomy Strategy focuses on three areas: (1) investments in research, innovation and skills; (2) strengthening the interaction of regulatory policies; and (3) strengthening markets and competitiveness in the bioeconomy (EC, 2012). In addition to the EU strategy, several Member States have developed national bioeconomy action plans for strengthening the sector and granting special attention in the regulatory process (M'Barek et al., 2014). Biotechnology plays an essential role in the bioeconomy, but to benefit from the advantages of a biological economy, innovative technologies need to be developed (Staffas et al., 2013), while bioenergy can play an essential role in ensuring energy security and energy sources diversification, and mitigating climate change.

Most current energy production and consumption strategies require companies to have a significant proportion of them coming from renewable sources; one of the technologies that can contribute to many of the sustainable development objectives is bioenergy. The concept is an intensely studied topic in the recent literature from a technical (Alsaleh et al., 2017; Koponen et al., 2018), environmental (Boschiero et al., 2016) and legislative perspective (Junginger et al., 2011). The economic, alongside social, ecological or innovative dimensions are areas that require a series of studies to capture most of the mechanisms, implications and effects that bioenergy can have on society, decision-making, business or policy. Current research topics discussed in the literature refer to: the impact of fossil fuel prices on bioenergy (Winchester and Ledvina, 2017), the uncertainties resulting from investments in the field of bioenergy (Jouveta et al., 2012), the interdependence of bioenergy with other industrial sectors (Bahel et al., 2013) or bioenergy implementation scenarios in the European Union (EU) by 2020 (Hoefnagels et al., 2014).

EU Directive 2009/28/EC on Renewable Energy requires Member States to develop strategies to meet renewable energy targets (EP, 2009). These National Renewable Energy Action Plans indicate an extensive commitment of Member States to biomass production. A biological-oriented economy would mean the substitution of fossil fuels and a significant increase in biomass demand (Ros et al., 2012). Bioenergy is used in developed countries as a sustainable alternative to hydrocarbons in areas such as transport, combined energy and heat production and residential heating, while for underdeveloped countries, bioenergy is the dominant fuel, especially in rural areas without access to electricity (WEC, 2016). This sector can create opportunities for both industrial development and economic growth (Bildiricia and Özaksoy, 2016).

Countries with a significant share of renewable energies also have a large share of bioenergy in the energy mix (WEC, 2016). Climate change and energy independence are the main factors for bioenergy development, also ensuring an important socio-economic impact by creating thousands of jobs globally across the value chain (Jin and Sutherland, 2016). Recent studies have 
outlined comprehensive bioenergy assessments regarding the economic issues, climate or environmental changes, as well as the feasibility and socio-economic impacts, using a variety of relevant sustainability criteria (Ragauskas, 2006; Fargione et al., 2008; Searchinger et al., 2008; Srebotnjaka și Hardi, 2011). Almost three-quarters of the world's renewable energy consumption involves bioenergy. This type of energy accounted for about $10 \%$ of total final energy consumption and $1.4 \%$ of global energy production in 2015 (WEC, 2016).

\subsection{Economic, environmental, innovative or regulatory impacts of bioenergy}

In a society based on accelerating economic progress, energy security is an extremely hot topic. The research area in the field is extremely comprehensive, starting from studies that analyze the aim of regulatory policies in diminishing energy dependence (Aslani et al., 2014) up to predicting the future energy dependence of a state using neural networks (Sözen, 2009) or exploring the international dimension of energy security, especially inter-state dependent relationships (Kanchana, et al., 2016). Most research attempts to determine national energy security performance, seeks solutions to diminish energy dependency, builds scenarios to predict future effects and implications of energy dependence at national, regional or international level, or studies policy harmonization and required standards (Magar et al., 2011; Owen et al., 2013; Xingang și Pingkuo, 2014; Matsumoto și Shiraki, 2018). Xingang and Pingkuo (2014) highlight the fact that bioenergy is an effective way of achieving a country's energy security, while Matsumoto and Shiraki (2018) claim that the energy security of a society with high levels of GDP is more influenced by the creation a low-carbon society, rather than specific socio-economic scenarios. At EU level, Magar et al. (2011) believes that bioenergy is an essential area of development but requires both a harmonization of policies in the field and a competitive market alongside an appropriate certification system. Owen et al. (2013) points out that in Sub-Saharan Africa, area-with low energy security, the benefits and opportunities of bioenergy are neglected. By adopting bioenergy, besides limiting climate change, the energy dependence of some states may also decline. Although Romania is considered one of the countries with significant potential regarding bioenergy (van Dam et al., 2009), research on this area is extremely rare. We came across studies refer only to assess the availability of agricultural and forestry residues for bioenergy production (Scarlat et al., 2011) or concerning production and price implications of bioenergy crops (Andrei et al., 2016).

\section{Research methodology}

\subsection{Research aim}

The research aims to analyze the implications, correlations and consequences of the transition towards a sustainable renewable bioenergy economy. The purpose of this article is to highlight the correlations between the production of bioenergy and its economic, environmental, technical and innovative dimensions. Some indicators were used to quantify the four dimensions: energy dependence, $\mathrm{CO}_{2}$ emissions, fossil fuel production, gross domestic product (GDP) per unit of energy used, renewable energy production and innovation degree in the field expressed by the number of new patents per year.

Since the adoption of the Paris Agreement (UN, 2015), the interest in mitigating climate changes has expanded worldwide. An important role in achieving the proposed goal is to increase the share of energy from renewable sources in the energy mix. Yang et al., (2016) 
state that many consumers are willing to pay extra for a growing portion of renewable energy, but renewable energy should come from a mix of renewable sources. Bioenergy involves many strengths over other technologies. The cost of bioenergy production remains lower compared to other renewable technologies, such as photovoltaic or wind technology (IRENA, 2013; WEC, 2016). Besides, bioenergy is storable and transportable energy that, in combination with wind or solar energy sources, can provide an acceptable solution to intermittent and storage problems (Akbi et al., 2017). To determine correlations between bioenergy production and the economic, innovation and associated energy mix of a country, the following hypotheses were formulated:

$\mathrm{H}_{1}$ : The level of bioenergy production is dependent on the level of economic efficiency.

$\mathrm{H}_{2}$ : The level of bioenergy production is dependent on conventional energy production.

$\mathrm{H}_{3}$ : The level of bioenergy production is dependent on the level of innovation at the societal level.

$\mathrm{H}_{4}$ : The quality of the prediction model tends to be lower in recent years.

A few researches have been identified to analyze the link between bioenergy generation and energy dependence of a country. Aslani et al. (2014) highlight the implications of renewable energy over Finland's energy dependence. At the same time, some researches suggest qualitative models for increasing energy security, reducing energy dependence, and applying in public policy development of developing economies (Shin et al., 2013). Guivarch and Monjon (2017) underline that enhancing security of energy supply can be challenging to achieve at the European level. Thus, to determine whether a state's energy dependence is influenced by bioenergy production, we formulate the following research hypothesis:

$\mathrm{H}_{5}$ : Increasing bioenergy production leads to a lower energy dependency of a country.

\subsection{Research design}

The research aims to highlight the gap between 25 EU Member States over the period 20072013 concerning bioenergy generation in relation to the energy dependence of each Member State and to identify whether there are correlations between bioenergy production and some economic, innovation or environmental indicators. Panel data were collected for each of the 28 EU Member States for the period 2007-2013. Statistical data were identified in the EUROSTAT (2016), IRENA (2018) or World Bank (2018) databases.

As the concept of bioenergy is in the attention of the European Commission and the European Parliament (EC, 2012), a sample of 25 EU countries has been established to assess the impact of bioenergy implementation measures on each EU member state. Denmark, Malta, Luxembourg, and Cyprus were removed from the sample. The first of the countries excluded from the analysis is an atypical case characterized by energy independence, which could affect the quality of the study, and the last three states because the selected indicators have insignificant values or no data are available. In addition to the EU Member States, Turkey has been included in the study due to its economic and geostrategic position and has a significant impact on the EU from several perspectives, not just from the renewable energy sector one.

The method used to test the linear regression model was the Least Squares Panel, using a series of data for 25 European countries over the period 2007-2013. The dependent variable

Vol. 21・ No. $50 \cdot$ February 2019 
was bioenergy production (BIO_ENG), and the independent variables that were wanted to be tested are shown in table no. 1 .

Table no. 1: Selected variables

\begin{tabular}{|l|l|l|}
\hline \multicolumn{1}{|c|}{ Acronym } & \multicolumn{1}{c|}{ Indicator } & \multicolumn{1}{c|}{ Unit } \\
\hline CO2EM & $\mathrm{CO}_{2}$ emissions & tones per capita \\
\hline ELCOAL & Energy from coal & \% of total production \\
\hline ELGAS & Energy from natural gases & \% of total production \\
\hline ELOIL & Energy from petrol & $\%$ of total production \\
\hline GDP_EUSE & GDP per energy use & 2011 PPP \$ per kg de petrol equivalent \\
\hline PATENTS & Patents renewable energy & Number of new patents \\
\hline RENEW & Renewable energy production & GWh/year \\
\hline
\end{tabular}

Following the multicollinearity test, the variables for which the VIF values were below the 2.5 were selected. For the other variables, the values were higher than this threshold, indicating the possible multicollinearity and implicitly the fact that the effects due to some variables cannot correctly be attributed.

Selected indicators (Table no. 2) for investigating correlations with bioenergy production were also analyzed in other relevant studies. Mahalingam and Orman (2018) identified, using panel analysis, the relationship between GDP and energy consumption in a state, while Ang and Goh (2018) dissected and discussed the fundamentals of the energy / GDP ratio along with the energy intensity index. From the perspective of innovation, the effects of policies and other factors that guide innovation (Schleich et al., 2017) or innovation areas in bioenergy were analyzed (Grando et al., 2017).

Table no. 2: Synthesis of used indicators

\begin{tabular}{|ccccc|}
\hline Indicator & Minimum & Maximum & Mean & Std. Deviation \\
\hline RENEW & 146.00 & 152108.00 & 28090.46 & 33680.49 \\
BIO_ENG & 7.00 & 46313.00 & 4689.78 & 7446.72 \\
PATENTS & 0.00 & 3317.00 & 278.60 & 574.48 \\
energ_depend & 11.90 & 90.40 & 54.21 & 20.28 \\
ELGAS & 0.40 & 64.28 & 22.98 & 18.97 \\
GDP_EUSE & 5.39 & 16.15 & 9.64 & 2.28 \\
\hline
\end{tabular}

In the first part of the data analysis, the linear panel regression was used. Also, the EViews application was used which allows us to access a class of estimated models using tools dedicated to panel data analysis. This type of analysis is widely used in scientific research in most areas of study. At a simple search in the Science Direct database, about 10,000 articles have been using this tool over the past five years. The general pattern of these equations is:

$$
\mathrm{Y}_{\mathrm{it}}=\alpha+\mathrm{X}_{\mathrm{it}} \beta+\delta_{\mathrm{i}}+\gamma_{\mathrm{t}}+\varepsilon_{\mathrm{it}}
$$

where $\mathrm{Y}_{\mathrm{it}}$ is the dependent variable, $\mathrm{X}_{\mathrm{it}}$ is a $\mathrm{k}$ dimensional vector of regressions and $\varepsilon_{\mathrm{it}}$ are the innovations for the $\mathrm{M}$ transverse units observed for $\mathrm{T}$ periods.

The terms $\delta_{\mathrm{i}}$ and $\gamma_{\mathrm{t}}$ represent the specific (random or fixed) effects for cross-section units or for certain periods (Necula, 2012). For each of the 7 years, a linear regression model having bioenergy as a dependent variable was run. The tested model is as follows:

BIO_ENG $=\mathrm{C}(1)+\mathrm{C}(2) *$ ELGAS $+\mathrm{C}(3) *$ GDP_EUSE $+\mathrm{C}(4) *$ PATENTS $+\mathrm{C}(5) *$ RENEW $+\varepsilon$ 
In the second part of the study, multidimensional scaling - PROXSCAL was used. Multidimensional scaling can be used to describe the structure of empirical data or to measure individual behaviors by developing a scale (Badescu, 1999). This multivariate exploratory technique can be used to visualize the proximity between objects in a small dimension space (Sava, 2004). Multidimensional scaling is one of the internal consistency procedures (Opincariu-Dan, 2011). Subsequently, the ANOVA test was applied to test the acceptability of the proposed model from a statistical perspective. The ANOVA test is one of the most widely used tools in various fields of study, from entrepreneurial education (Peterman and Kennedy, 2003) to health and safety (Sow, 2014) or medicine (Patel et al., 2015). Exploratory research has been aimed at outlining guidelines on how bioenergy influences or is influenced by renewable energy production and the country's energy dependency. The data were processed using IBM SPSS Statistics 25 and the EViews econometric program.

\section{Results and discussions}

\subsection{Bioenergy economic, ecological and innovative relationships}

The data first indicate the high quality of the model, given that the Adjusted R-squared value is 0.728. The Akaike and Schwarz values are at the level that allows this model to be considered a valid and high-quality one. Thus, using the Panel Least Squares analysis and the regression model set out in Formula 2 for the period 2007-2013, the values in Table no. 3 were obtained.

Table no. 3: Panel Least Squares

\begin{tabular}{|c|r|r|r|r|}
\hline & Coefficient & Std. Error & t-Statistic & \multicolumn{1}{c|}{ Prob. } \\
\hline $\mathrm{C}(1)$ & 7353.112 & 1441.795 & 5.099 & 0.000 \\
\hline $\mathrm{C}(2)$ & 42.526 & 21.560 & 1.972 & 0.050 \\
\hline $\mathrm{C}(3)$ & -856.756 & 187.754 & -4.563 & 0.000 \\
\hline $\mathrm{C}(4)$ & 7.429 & 0.705 & 10.534 & 0.000 \\
\hline $\mathrm{C}(5)$ & 0.091 & 0.013 & 6.984 & 0.000 \\
\hline R-squared & 0.735 & \multicolumn{2}{|c|}{ Mean dependent var } & 4689.783 \\
\hline Adjusted R-squared & 0.728 & \multicolumn{2}{|c|}{ S.D. dependent var } & 7446.721 \\
\hline S.E. of regression & 3877.831 & Akaike info criterion & 19.392 \\
\hline Sum squared resid & $2.56 \mathrm{E}+09$ & \multicolumn{2}{|c|}{ Schwarz criterion } & 19.482 \\
\hline Log likelihood & -1691.808 & Hannan-Quinn criter. & 19.428 \\
\hline F-statistic & 117.913 & Durbin-Watson stat & 0.147 \\
\hline Prob(F-statistic) & 0.000 & \multicolumn{2}{|l}{} \\
\hline
\end{tabular}

At the same time, it can be noticed that for all parameters, sig. is lower than the threshold of 0.05 , which means that each of them has a significantly different contribution to 0 in predicting bioenergy. The resulting form of the equation attached to the model is:

BIO_ENG $=7353.11+42.53 *$ ELGAS $-856.76 *$ GDP_EUSE + 7.43*PATENTS + 0.09*RENEW

Therefore, for each unit of electricity produced from methane gas, the level of bioenergy increases by 42.53 units, with the other factors not varying. Under the same conditions, the increase with a unit of economic efficiency implies the decrease of 857 units of bioenergy, the increase with a unit of the degree of innovation leads to an increase of 7.43 units of bioenergy and the increase with one unit of the level of energy from renewable sources to 0.09 units of bioenergy. 
Concerning GDP_EUSE, it is noticed that the parameter of this variable has a negative value $(-856.76)$, which would mean that the bioenergy level is rather negatively correlated with the level of economic efficiency. At European level, countries with relatively low economic efficiency produce more bioenergy compared to countries with high economic efficiency. This confirms the first research hypothesis $\left(\mathrm{H}_{1}\right)$. At the same time, the data indicate a positive relationship between the level of bioenergy and that of energy production in natural gas $\left(\mathrm{H}_{2}\right)$. Thus, the EU states surveyed are in line with existing regulatory policies at the European level, using conventional renewable energy sources with low environmental impact, such as natural gas, in addition to renewable energy.

On the other hand, the bioenergy level positively correlates with the level of innovation existing in society, expressed by the number of patents. This confirms the third hypothesis $\left(\mathrm{H}_{3}\right)$, and it can be emphasized that innovative companies' value more renewable energy production or non-conventional methods that do not harm the environment. The quality of the model is illustrated by figure no. 1 .

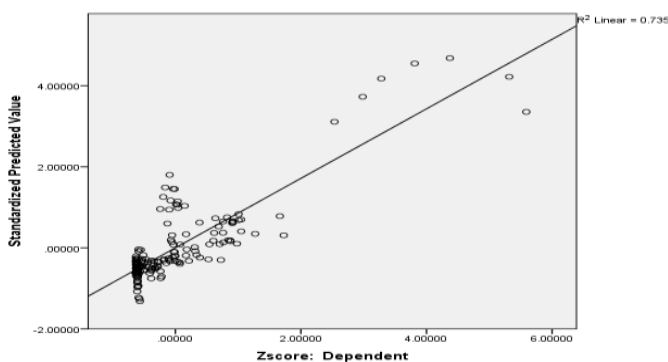

Figure no. 1: Prediction values distribution
Tabel no. 4: Residuals values

\begin{tabular}{|cccc|}
\hline Year & Mean & N & Std. Deviation \\
\hline 2007 & -0.172 & 25 & 0.659 \\
2008 & -0.204 & 25 & 0.730 \\
2009 & -0.206 & 25 & 0.826 \\
2010 & -0.211 & 25 & 0.962 \\
2011 & 0.018 & 25 & 0.883 \\
2012 & 0.270 & 25 & 1.117 \\
2013 & 0.505 & 25 & 1.402 \\
Total & 0.000 & 175 & 0.988 \\
\hline
\end{tabular}

It can be seen that the prediction values are distributed diagonally alongside the real ones, which validates a linear pattern. If we analyze the average of residual values (Table no. 4), it is observed that if there is an overestimation of the values of bioenergy in the period $2007-$ 2010 with averages between -0.17 and -0.21 , after 2011 the tendency is underestimated. Moreover, the average of underestimation is more than twice as high as 0.50 . Thus, the quality of the model tends to be lower in the last years of the series, thus confirming the fourth hypothesis $\left(\mathrm{H}_{4}\right)$.

The quality of the model according to the national data shows a better prediction in the Central European countries (Croatia, Austria, Czech Republic, Greece, Hungary) and a lower one, with overestimation tendencies in the southern Mediterranean countries and with underdevelopment tendencies in the northern states.

\subsection{Bioenergy and energy dependence}

The application of multidimensional scaling has been aimed at determining the relations existing between the analyzed countries through the generation of bioenergy, the generation of renewable energy and energy dependency. At the level of 2007, one compact group consisting of 16 countries can be observed (Figure no. 2). This grouping is because, at the level of the analyzed year, most of these countries did not have a highly developed bioenergy sector. At the same time, Germany can be remarked, which is positioned itself and at a very distance from all the other states. Starting with 2011, it is highlighted formation of the second group of countries that have given increased importance to the generation of bioenergy. 
Interesting is Austria's track record from 2007 to 2011, which seems to join more the original group than the new group of states from Italy, Spain, Sweden and France.

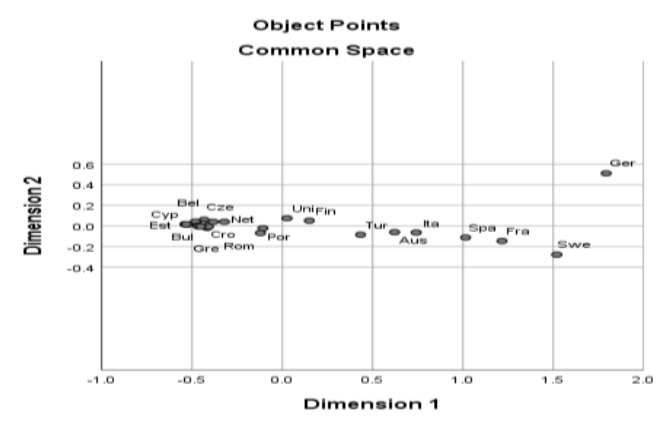

Figure no. 2: Multidimensional Scaling Chart, 2007

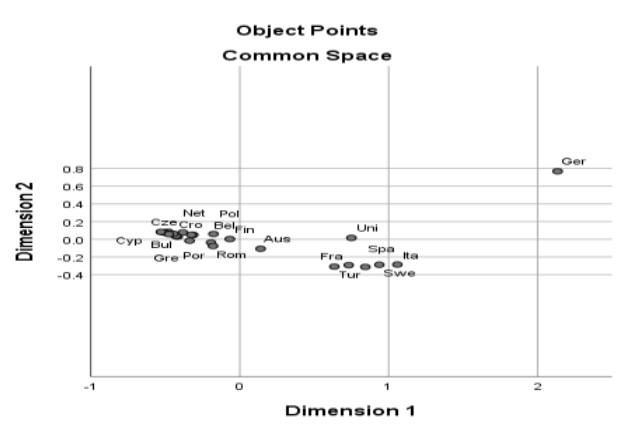

Figure no. 3: Multidimensional Scaling Chart, 2015

At the level of 2015 (Figure no. 3), EU member countries are concentrated in two almost compact groups. Germany is also distinguishing this time, recording a progress from the bioenergy perspective. Analyzing the preliminary data, it can be noticed that Austria, in fact, remains in a relatively constant position, not registering significant changes in the generation of bioenergy or in the production of renewable energy. Great Britain moves into the group of countries that are progressing in the area of the analyzed indicators. And the initial cluster formed is increasingly clogging, reducing existing differences from the bioenergy generation perspective, improving both generation and storage capacities; most of them reducing their energy dependence. The data show a tendency of grouping, over time, of the analyzed countries into two distinct groups as national experience regarding renewable energy and energy dependence.

Over the analyzed period, the R square value increases from 0.518 to 0.628 , which highlights the increase in predictive power of predictors in explaining the independent variable, bioenergy production. Another observation is that during the economic crisis, the model is weaker, indicating that other factors influence the explanation of bioenergy, or the influence of the level of energy dependency becomes much less. It can be pointed out that, during the analyzed period, the value $\mathrm{F}$ is high, because sig. be $<0.000$.

As can be seen in table no. 5, bioenergy production negatively correlates with the degree of energy dependence. Each low percentage of energy dependence means an increase of about $35,500 \mathrm{GWh}$ of bioenergy (coefficient $\beta 1$ ). However, the fact that the $\mathrm{t}$ value for the independent energy_depend variable is below the 1.96 threshold means that there is a higher probability that the coefficient of this variable is not significantly different from 0 . On the other hand, bioenergy positively correlates with the level of renewable energy. For every GWh of renewable energy produced, the contribution of bioenergy is $0.19 \mathrm{GWh}$ (coefficient $\beta 1$ ), almost one-fifth. At the same time, the evolution of this coefficient is observed, its value rising from 0.14 to 0.19 . Also, the $t$ values are higher than the threshold of 1.96 , the equivalent of a sig. $<0.05$. Coefficients whose values of sig. are less than 0.05 are significantly different from 0 for a $95 \%$ confidence threshold. 
Table no. 5: Linear regression coefficients

\begin{tabular}{|c|c|c|c|c|c|c|c|}
\hline \multicolumn{8}{|c|}{ Coefficients $^{a}$} \\
\hline & & \multirow{2}{*}{ year } & \multicolumn{2}{|c|}{$\begin{array}{c}\text { Unstandardized } \\
\text { Coefficients }\end{array}$} & \multirow{2}{*}{\begin{tabular}{|c|}
$\begin{array}{c}\text { Standardized } \\
\text { Coefficients }\end{array}$ \\
Beta \\
\end{tabular}} & \multirow[b]{2}{*}{ t } & \multirow[b]{2}{*}{ Sig. } \\
\hline & & & B & Std. Error & & & \\
\hline \multirow[t]{3}{*}{2007} & \multirow[t]{3}{*}{1} & (Constant) & 2597,623 & 2032,416 & & 1,278 & 0,213 \\
\hline & & energ_depend & $-39,868$ & 31,193 & $-0,174$ & $-1,278$ & 0,213 \\
\hline & & energ_renew & 0,141 & 0,027 & 0,722 & 5,301 & 0,000 \\
\hline \multirow[t]{3}{*}{2008} & \multirow[t]{3}{*}{1} & (Constant) & 2422,685 & 2349,867 & & 1,031 & 0,313 \\
\hline & & energ_depend & $-35,773$ & 35,680 & $-0,140$ & $-1,003$ & 0,326 \\
\hline & & energ_renew & 0,145 & 0,028 & 0,715 & 5,115 & 0,000 \\
\hline \multirow[t]{3}{*}{2009} & \multirow[t]{3}{*}{1} & (Constant) & 2762,034 & 2462,896 & & 1,121 & 0,273 \\
\hline & & energ_depend & $-42,043$ & 39,337 & $-0,154$ & $-1,069$ & 0,296 \\
\hline & & energ_renew & 0,149 & 0,030 & 0,706 & 4,908 & 0,000 \\
\hline \multirow[t]{3}{*}{2010} & \multirow[t]{3}{*}{1} & (Constant) & 3360,923 & 2816,313 & & 1,193 & 0,244 \\
\hline & & energ_depend & $-47,671$ & 44,879 & $-0,163$ & $-1,062$ & 0,299 \\
\hline & & energ_renew & 0,138 & 0,032 & 0,655 & 4,271 & 0,000 \\
\hline \multirow[t]{3}{*}{2011} & \multirow[t]{3}{*}{1} & (Constant) & 2892,331 & 2828,725 & & 1,022 & 0,317 \\
\hline & & energ_depend & $-47,004$ & 45,035 & $-0,141$ & $-1,044$ & 0,307 \\
\hline & & energ_renew & 0,170 & 0,030 & 0,751 & 5,569 & 0,000 \\
\hline \multirow[t]{3}{*}{2012} & \multirow[t]{3}{*}{1} & (Constant) & 2630,723 & 3319,692 & & 0,792 & 0,436 \\
\hline & & energ_depend & $-45,137$ & 52,671 & $-0,115$ & $-0,857$ & 0,400 \\
\hline & & energ_renew & 0,174 & 0,031 & 0,749 & 5,590 & 0,000 \\
\hline \multirow[t]{3}{*}{2013} & \multirow[t]{3}{*}{1} & (Constant) & 2031,578 & 3465,337 & & 0,586 & 0,563 \\
\hline & & energ_depend & $-37,243$ & 56,519 & $-0,090$ & $-0,659$ & 0,516 \\
\hline & & energ_renew & 0,169 & 0,031 & 0,747 & 5,460 & 0,000 \\
\hline \multirow[t]{3}{*}{2014} & \multirow[t]{3}{*}{1} & (Constant) & 1546,293 & 3519,754 & & 0,439 & 0,664 \\
\hline & & energ_depend & $-34,088$ & 57,315 & $-0,077$ & $-0,595$ & 0,558 \\
\hline & & energ_renew & 0,185 & 0,030 & 0,780 & 6,065 & 0,000 \\
\hline \multirow[t]{3}{*}{2015} & \multirow[t]{3}{*}{1} & (Constant) & 1462,097 & 3548,699 & & 0,412 & 0,684 \\
\hline & & energ_depend & $-34,467$ & 55,186 & $-0,075$ & $-0,625$ & 0,538 \\
\hline & & energ_renew & 0,188 & 0,028 & 0,807 & 6,744 & 0,000 \\
\hline
\end{tabular}

The research results indicate the correlation between bioenergy in relation to renewable energy production and energy dependency of EU states, confirming the fifth hypothesis of research $\left(\mathrm{H}_{5}\right)$. The explanatory model of bioenergy production in relation to the volume of renewable energy and the level of energy dependence shows a tendency to improve the explanatory power of this model, as well as an influence of the macroeconomic conditions on the adequacy level.

\section{Conclusions}

Considering the literature as well as the own empirical observations, the study highlights a series of correlations between the most important bioenergy indicators in order to create a benchmark for the transition to bioeconomy. Based on the designed model, the associations between bioenergy production and the indicators reflecting the country's economic efficiency, innovation level or energy sector capabilities are highlighted. The study indicates that bioenergy negatively correlates with the economic efficiency of a state, quantified by GDP per unit of energy used and positively with natural gas or innovation. It was also 
highlighted the gap between the 25 states analyzed concerning the production of bioenergy in 2007-2015.

Based on the results obtained, one of the main contributions of the research carried out to the development of the specialized literature is the identification of the correlations between the production of bioenergy on the one hand and the energy dependence and the production of renewable energy on the other. At the same time, it is highlighted that the output of bioenergy is influenced by some significant economic phenomena, such as the economic crisis, and this influence has been quantified. Starting from the fact that Central and Eastern Europe has an important potential for production and export of bioenergy (van Dam et al., 2009), research highlights the implications of bioenergy production for renewable energy production. The study also shows to what extent the modification of some economic, environmental or innovation indicators influences the production of bioenergy, while proposing an own analysis model.

The study also has a couple of managerial, regulatory or strategic implications. The first one refers to the fact that bioenergy can increase the energy security of a state, being a cheaper alternative to fossil fuels or other renewable energy sources. The presented results suggest a series of changes that can be made both to regulatory policies and to the way of subsidizing renewable energy sources. For the elaboration of the national strategies, the research proposes a model of quantification of the changes determined by the evolution of specific national indicators.

The research focuses on the relationship between the bioenergy and a number of significant socio-economic indicators and on identifying the gap between the EU states from the bioenergy perspective. Although, as presented above, our findings have some theoretical implications, they are only a first step in understanding the correlations between bioenergy and other socio-economic indicators that it influences or is influenced both during the economic crisis, and beyond. Understanding how these correlations change, we can anticipate reactions to new economic crises, and can help mitigate their effects on bioenergy.

One of the main limits of the study is the limitation of the analysis at the level of the EU Member States. Thus, the conclusions and results cannot be extrapolated globally or at the level of other continents. Another limitation was the lack of data for some countries over a more extended period to allow the identification of different types of correlations. The complexity, timeliness and importance of this field constantly require new research, new concepts, ideas and models as well as additional case studies to understand the economic, social, environmental, legislative and business aspects of phenomena. Starting with this current research, a further step is the application of global or continental analysis to identify whether there are differences between continents.

\section{References}

Akbi, A., Saber, M., Aziza, M. and Yassaa, N., 2017. An overview of sustainable bioenergy potential in Algeria. Renewable and Sustainable Energy Reviews, 72, pp.240-245.

Alsaleh, M., Abdul-Rahim, A.S. and Mohd-Shahwahid, H.O., 2017. Determinants of technical efficiency in the bioenergy industry in the EU28 region. Renewable and Sustainable Energy Reviews, 78, pp.1331-1349. 
Andrei, J.V., Ion, R.A., Popescu, H.G., Nica, E. and Zaharia, M., 2016. Implications of agricultural bioenergy crop production and prices in changing the land use paradigmThe case of Romania. Land Use Policy, 50, pp.399-407.

Ang, B.W. and Goh, T., 2018. Bridging the gap between energy-to-GDP ratio and composite energy intensity index. Applied Energy, 119, pp.105-102.

Appunn, K., 2016. Bioenergy in Germany - facts and figures on development, support and investment. [online] Available at: <https://www.cleanenergywire.org/ factsheets/bioenergy-germany-facts-and-figures-development-support-and-investment> [Accessed 10 September2018].

Aslani, A., Helo, P. and Naaranoja, M., 2014. Role of renewable energy policies in energy dependency in Finland: System dynamics approach. Applied Energy, 113, pp.758-765.

Bahel, E., Marrouch, W. and Gaudet, G., 2013. The economics of oil, biofuel and food commodities. Resource and Energy Economics, 35(4), pp.599-617.

Bădescu, G., 1999. Metode de reducere a datelor. În: Rotariu T., coord., 1999. Metode statistice aplicate în ştiinţele sociale. Iași: Polirom, pp.254-271.

Bildiricia, M. and Özaksoy, F., 2016. Woody biomass energy consumption and economic growth in Sub-Saharan Africa. Procedia Economics and Finance, 38, pp.287-293.

Boschiero, M., Cherubini, F., Nati, C. and Zerbe, S., 2016. Life cycle assessment of bioenergy production from orchards woody residues in Northern Italy. Journal of Cleaner Production, 112(4), pp.2569-2580.

Chen, C.C., McCarl, B.A., Chang, C.C. and Tso, C., 2011. Evaluation the potential economic impacts of Taiwanese biomass energy production. Biomass Bioenergy, 35, pp.1693-1701.

Dabija, D.C., Bejan, B. and Grant, D., 2018. The impact of consumer green behaviour on green loyalty among retail formats: A Romanian case study. Moravian Geographical Reports, 26(3), pp.173-185.

Dabija, D.C., Pop, C.M. (2013). Green marketing - Factor of Competitiveness in Retailing. Environmental Engineering and Management Journal, 12(2), pp.393-400.

Do Paco, A., Alves, H., Shiel, C., Filho, W.L., 2013. Development of a green consumer behaviour model. International Journal of Consumer Studies, 37(4), pp.414-421.

European Commision (EC), 2012. Innovating for sustainable growth: A bioeconomy for Europe. Brussels: European Commision.

European Parliament (EP), 2009. Directive 2009/28/EC. Brussels: European Parliament. [online] Available at: <https://eur-lex.europa.eu/legal-content/EN/ALL/?uri=CELEX: 32009L0028> [Accessed 16 September 2018].

Eurostat, 2016. Renewable Energy Statistics. Eurostat-Statistics Explained 2016. [online] Available at: <http://ec.europa.eu/eurostat/statistics-explained/index.php> [Accessed 10 September 2018].

Fargione, J., Hill, J., Tilman, D. and Polasky, S.H., 2008. Land clearing and the biofuel carbon debt. Science, 319, pp.1235-1238.

Fonseca, A., Macdonald, A., Dandy, E. and Valenti, P., 2011. The state of sustainability reporting at Canadian universities. International Journal of Sustainability in Higher Education, 12(1), pp.22-40.

Guivarch, C. and Monjon, S., 2017. Identifying the main uncertainty drivers of energy security in a low-carbon world: The case of Europe. Energy Economics, 64, pp.530-541. 
Global Energy Assessment (GEA), 2011. Toward a Sustainable Future. Viena: International Institute for Applied Systems Analysis.

Grando. R.F. et al., 2017. Technology overview of biogas production in anaerobic digestion plants: A European evaluation of research and development. Renewable and Sustainable Energy Reviews, 80, pp.44-53.

Hoefnagels, R., Resch, G., Junginger, M. and Faaij, A., 2014. International and domestic uses of solid biofuels under different renewable energy support scenarios in the European Union. Applied Energy, 131, pp.19-157.

International Energy Agency (IEA), 2012. World Energy Outlook 2012. Paris: IEA Publications.

International Energy Agency (IEA), 2011. Technology roadmap: biofuels for transport. Paris: IEA Publications.

International Renewable Energy Agency (IRENA), 2013. Renewable power generation costs in 2012: an overview. Renewable power generation costs by technology. Abu Dhabi: IRENA.

International Renewable Energy Agency (IRENA), 2018. International Renewable Energy Agency Database, 2018. [online] Available at: <http://resourceirena.irena.org/gateway/ dashboard> [Accessed 12 July 2018].

IPCC, 2014. Climate change 2014: AR5 synthesis report. In: Core Writing Team, Pachauri, R.K., Meyer, L.A., eds. 2014. Contribution of Working Groups I, II and III to the Fifth Assessment Report of the Intergovernmental Panel on Climate Change. Geneva: IPCC.

Jin, E. and Sutherland, J.W., 2016. A proposed integrated sustainability model for a bioenergy system. Procedia CIRP, 48, pp.358-363.

Jouveta, P.-A., Le Cadre, E. and Orset, C., 2012. Irreversible investment, uncertainty, and ambiguity: The case of bioenergy sector. Energy Economics, 34(1), pp.45-53.

Junginger, M., van Dam, J., Zarrilli, S. and Ali, F., 2011. Opportunities and barriers for international bioenergy trade. Energy Policy, 39(4), pp.2028-2042.

Kanchana, K., McLellan, B.C. and Unesaki, H., 2016. Energy dependence with an Asian twist? Examining international energy relations in Southeast Asia. Energy Research \& Social Science, 21, pp.123-140.

Kirmani, M.D. and Khan, M.N., 2016. Environmental concern to attitude towards green products: Evidence from India. Serbian Journal of Management, 11(2), pp.159-179.

Koponen, K., Soimakalliob, S., Klinec, K.L., Cowied, A. and Brandãoe, M., 2018. Quantifying the climate effects of bioenergy - Choice of reference system. Renewable and Sustainable Energy Reviews, 81(2), pp.2271-2280.

Kung, C.C., McCarl, B.A., Chen, C.C. and Cao, X.Y., 2014. Environmental impact and bioenergy production from pyrolysis in Taiwan. Energy \& Environment, 25(1), pp.13-39.

M'Barek, R., Philippidis, G., Suta, C., Vinyes, C., Caivano, A., Ferrari, E., Ronzon, T., Sanjuan Lopez, A. and Santini, F., 2014. Observing and analyzing the bioeconomy in the EU-adapting data and tools to new questions and challenges. Bio-based and Applied Economics, 1, pp.83-91.

Magar, S. B., Pelkonen, P., Tahvanainen, L., Toivonen, R. and Toppinen, A., 2011. Growing trade of bioenergy in the EU: Public acceptability, policy harmonization, European standards and certification needs. Biomass and Bioenergy, 35(8), pp.3318-3327. 
Mahalingam, B. and Orman, W.H., 2018. GDP and energy consumption: A panel analysis of the US. Applied Energy, 213, pp.208-218.

Matsumoto, K. and Shiraki, H., 2018. Energy security performance in Japan under different socioeconomic and energy conditions. Renewable and Sustainable Energy Reviews, 90, pp.391-401.

Matzenberger, J., Kranzi, L., Tromborg, E., Junginger, M., Daiaglou, V., Sheng Goh, C. and Keramidas, K., 2015. Future perspectives of international bioenergy trade. Renewable and Sustainable Energy Reviews, 43, pp.926-941.

Mccormick, K. and Willquist, K., 2015. The Bioeconomy: An introduction to the world of bioenergy. Lund: Lund University.

Necula, C., 2012. Econometrie. Suport de curs. [online] Available at: < http://www.cnp.ro/ user/repository/econometrie.nivel1.v3.2>, [Accessed 30 November 2018].

OECD/IEA, 2011. International Energy Agency World Energy Outlook 2011. Paris: IEA Publications.

Opincariu-Dan, C., 2011. Statistică aplicată în ştiinţele socio-umane: analiza relaţiilor şi a diferenţelor statistice. Constanţa: Psihologul expert.

Owen, M., van der Plas, R. and Sepp, S., 2013. Can there be energy policy in Sub-Saharan Africa without biomass? Energy for Sustainable Development, 17(2), pp.146-152.

Ozturk, I., Aslan, A. and Kalyoncu, H., 2010. Energy consumption and economic growth relationship: Evidence from panel data for low and middle income countries. Energy Policy, 38(8), pp.4422-4428.

Patel, S., Naik, V. and Patel, P., 2015. An analysis of application of multiple comparison tests (post-hoc) in Anova in recently published medical research literature. National Journal of Community Medicine, 6(1), pp.117-120.

Peterman, N.E. and Kennedy, J., 2003. Enterprise education: Influencing Students' perceptions of entrepreneurship. Entrepreneurship Theory and Practice, 28(2), pp.129-144.

Ragauskas, A.J., 2006. The path forward for biofuels and biomaterials. Science, 311, pp.484-489.

Ros, J. et al., 2012. Sustainability of biomass in a bio-based economy. Hague: PBL Netherlands Environmental Assessment Agency.

Sava, F., 2004. Analiza datelor în cercetarea psihologică-metode statistice complementare. Cluj-Napoca: Editura ASCR.

Scarlat, N., Blujdea, V. and Dallemand, J.-F., 2011. Assessment of the availability of agricultural and forest residues for bioenergy production in Romania. Biomass and Bioenergy, 35, pp.1995-2005.

Scarlat, N., Dallemand, J.-F., Monforti-Ferrario, F. and Nita, V., 2015. The role of biomass and bioenergy in a future bioeconomy: Policies and facts. Environmental Development, 15 , pp.3-34.

Searchinger, T., Heimlich, R., Houghton, R.A., Dong, F., Elobeid, A., Fabiosa, J., Tokgoz, S., Hayes, D. and Yu, T.H., 2008. Use of U.S. croplands for biofuels increases greenhouse gases through emissions from land use change. Science, 319, pp. 1238-1240.

Schleich, J., Walz, R. and Ragwitz, M., 2017. Effects of policies on patenting in wind-power technologies. Energy Policy, 108, pp.684-695. 
Shin, J., Shina, W.-S. and Lee, C., 2013. An energy security management model using quality function deployment and system dynamics. Energy Policy, 54, pp.72-86.

Sillanpää, M. and Ncibi, C., 2017. A Sustainable Bioeconomy. Cham: Springer International Publishing AG, pp.29-53.

Silveira, S., Khatiwada, D., Leduc, S., Kraxner, F., Venkata, B.K., Tilvikine, V., Gaubyte, V., Romagnoli, F., Tauraite, E., Kundas, S., Blumberga, D., Peterson, K., Utsar, K., Vigants, E., Kalinichenko, A., 2017. Opportunities for bioenergy in The Baltic Sea Region. Energy Procedia, 128, pp.157-164.

Sow, M.T., 2014. Using ANOVA to examine the relationship between safety \& security and human development. Journal of International Business and Economics, 2(4), pp.101-106.

Sözen, A., 2009. Future projection of the energy dependency of Turkey using artificial neural network. Energy Policy, 37(11), pp.4827-4833.

Srebotnjaka, T. and Hardi, P., 2011. Prospects for sustainable bioenergy production in selected former communist countries. Ecological Indicators, 11, pp.1009-1019.

Staffas, L., Gustavsson, M. and McCormick, K., 2013. Strategies and policies for the bioeconomy and bio-based economy: An analysis of official national approaches. Sustainability, 5, pp.2751-2769.

United Nations (UN), 2015. Transforming our world: The 2030 agenda for sustainable development, New York: United Nations.

van Dam, J., Faaij, A.P.C., Lewandowski, I. and Van Zeebroeck, B., 2009. Options of biofuel trade from Central and Eastern to Western European countries. Biomass and Bioenergy, 33, pp.728-744.

Wang, S., Li, Q., Fang, C. and Zhou, C., 2016. The relationship between economic growth, energy consumption, and CO2 emissions: Empirical evidence from China. Science of The Total Environment, 542(A), pp.360-371.

Winchester, N. and Ledvina, K., 2017. The impact of oil prices on bioenergy, emissions and land use. Energy Economics, 65, pp.219-227.

World Bank, 2018. Sustainable Energy for All (SE4ALL) Database. 2018. [online] Available at: <https://data.worldbank.org/indicator/EG.ELC.RNEW.ZS>, [Accessed 30 August 2018].

World Economic Forum (WEF), 2018. Globalization 4.0. [online] Available at: < https://www.weforum.org/focus/globalization-4-0>, [Accessed 30 November 2018].

World Energy Council (WEC), 2016. World Energy Resources: Bioenergy 2016, London: World Energy Council.

Xingang, Z. and Pingkuo, L., 2014. Focus on bioenergy industry development and energy security in China. Renewable and Sustainable. Energy Reviews, 32, pp.302-312.

Yang, Y., Solgaard, H.S. and Haider, W., 2016. Wind, hydro or mixed renewable energy source: Preference for electricity products when the share of renewable energy increases. Energy Policy, 97, pp.521-531. 